Annals of Warsaw University of Life Sciences - SGGW

Land Reclamation No 47 (1), 2015: 19-29

(Ann. Warsaw Univ. Life Sci. - SGGW, Land Reclam. 47 (1), 2015)

\title{
Variability of morphological conditions of the Vistula river channel in the section Czerwińsk-Kępa Polska
}

\author{
ZBIGNIEW POPEK, MICHAŁ WASILEWICZ \\ Department of Water Engineering, Warsaw University of Life Sciences - SGGW
}

\begin{abstract}
Variability of morphological conditions of the Vistula river channel in the section Czerwińsk-Kępa Polska. The paper presents an assessment of morphological changes that occurred in the Vistula river channel in selected section of about $33 \mathrm{~km}$ long, located in the middle of the Vistula river course between Czerwińsk and Kępa Polska (km 576-609). Based on the analysis of archival material from 1972-2009, a characteristics of river channel changes, taking primarily into account the horizontal layout (shape in the plan), was obtained. An attempt was made to estimate the trends and rate of transformation of the following parameters in the river channel: width, length, and position of the riverbanks, abundance and size of islands and fluvial deposits, as well as their percentage in the total area of the main river channel and the floodplain area between levees.
\end{abstract}

Key words: river channel morphology, braided river, Vistula river

\section{INTRODUCTION}

Between Czerwińsk and Kępa Polska, the Vistula river flows through the valley typical for most large lowland rivers. This section is located in the western part of the Warsaw Basin, on the border with Płock Basin (Fig. 1). This mesoregion belongs to the Central-Mazovia Lowland macroregion. The Płock Basin is considered the beginning of the Torun-Eberswalde ice-marginal valley as a part of the Southern-Baltic Lake district subprovince (Kondracki 1994).

The Vistula river channel section from $\mathrm{km} 578$ to $\mathrm{km} 607$ runs more or less in the center of ice-marginal valley, the width of which varies from a few hundred meters to $6 \mathrm{~km}$ (around Kępa Sempławska), usually about $4 \mathrm{~km}$. Two floodplain terraces (lower and upper), as well as alluvial terrace were formed in the valley. Lower flood terrace is raised from 0.5 to $2.5 \mathrm{~m}$ above the mean water level in the Vistula river and is present across the entire valley up to the width of $500 \mathrm{~m}$. The upper flood terrace occurs in fragments - in the area between Wyszogród and Kępa Polska (left bank of the river), as well as at the mouth of the Bzura river. This terrace rises from 1.5 to $5 \mathrm{~m}$ above the lower flood terrace, wherein it is characterized by varying width from about $300 \mathrm{~m}$ to $4 \mathrm{~km}$. The alluvial terrace is present on both banks of the floodplain and extends to the edge of the plateau (Ruszczyńska-Szenajch 1970, Popek et al. 2009).

The levees are landscape elements of the floodplain. They appeared in the second half of $19^{\text {th }}$ century along with Vistula river regulation. Groins and longitudinal regulation structures in the form of fascine-stone bands are another 


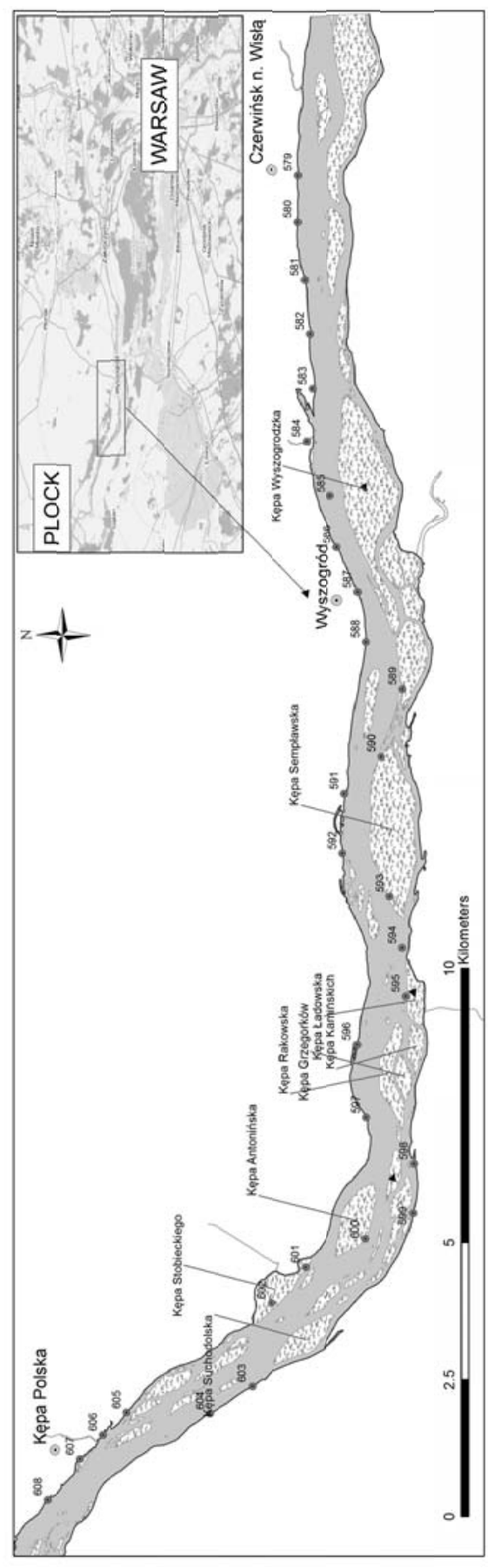

regulatory elements in the Vistula river valley. All the side arms of the river were dammed with transverse structures and embankments controlling the out-of-riverbed water flow towards the mainstream axis, were piled. According to the development plan, fragment of the Vistula river near Wyszogród is of $300 \mathrm{~m}$ regulatory width at the average water level conditions.

On the river reach between Czerwińsk and Wyszogród, in the northern part, the Vistula riverbed is limited with Płońska Plateau slope, which is its right riverbank rising up to a height of $35 \mathrm{~m}$. It is subject to slow erosion, which is clearly visible in Wyszogród between $\mathrm{km} 586$ and km 588 (Bajkiewicz-Grabowska and Danielak 1996, Banach 1998).

\section{MATERIALS AND METHODS}

Following morphological parameters of the river channel were analyzed in the study: width, length, and localization of the riverbanks, abundance and area of islands, as well as their percentage in the total river channel area. Measurements were made within the main riverbed zone, i.e. the space of the river channel defined by average water levels. We analyzed archival cartographic materials from 1972-1992 (three topographic maps), as well as a digital situation-elevation map from 2003 and orthophotomap from 2009.

Maps calibration and their vectorization along with measurements of selected characteristics of the river channel were performed by means of ArcGIS software. The river channel width measurements were made along the transverse profiles plotted every $1 \mathrm{~km}$ of the 
river course. A total of 34 profiles were determined in the examined section of the Vistula river. These data allowed to calculate the average width of the river channel in a given year.

Geometric centers of islands (gravity centers) have been generated automatically in ArcGIS software by the function of converting polygons to point objects.

\section{RESULTS AND DISCUSSION}

The average width of the Vistula river channel within the studied section was the biggest in 1972-1974 and was around $1,130 \mathrm{~m}$. In the following years, the average width decreased to about $1,116 \mathrm{~m}$ in 1992, then increased by $2 \mathrm{~m}$ in 2003, to be reduced again to $1,094 \mathrm{~m}$ in 2009 . The decreasing width of the river channel was affected by the accumulation of material near the riverbanks, which caused that part of point bars and islands merged with the banks thereby creating a cutoff side river channel. Increase in the river channel width could be caused by floods in 1997-2001 (Table 1).

TABLE 1. The mean annual water stages at Wyszogród gauge station during realisation of cartographic materials and the river channel average width's changes on the Vistula river reach Czerwińsk-Kępa Polska (km 576-609)

\begin{tabular}{|c|c|c|c|}
\hline \multirow{2}{*}{ Year } & $\begin{array}{c}\text { Water stage } \\
(\mathrm{cm})\end{array}$ & \multicolumn{2}{|c|}{$\begin{array}{r}\text { Average river channel } \\
\text { width in } 34 \text { transverse } \\
\text { profiles }(\mathrm{m})\end{array}$} \\
\cline { 3 - 4 } & & in the & $\begin{array}{c}\text { changes in } \\
\text { following } \\
\text { period }\end{array}$ \\
\hline 1974 & 240 & 1129 & - \\
\hline 1982 & 245 & 1119 & -10 \\
\hline 1992 & 245 & 1116 & -3 \\
\hline 2003 & 247 & 1118 & 2 \\
\hline 2009 & 250 & 1094 & -24 \\
\hline
\end{tabular}

The effect of accumulation process on changes in the river channel width is visible especially along the river course. Maximum width, about $1,667 \mathrm{~m}$, was recorded at $\mathrm{km} 602$ in 1974. The river channel was characterized by the greatest width and relatively small variation of the width within entire analysis period - from $1,618 \mathrm{~m}$ in 1982 to $1,639 \mathrm{~m}$ in 2009. The smallest river channel width of about $621 \mathrm{~m}$, was recorded in Kępa Polska (km 607) in 2003-2009. Width at that point clearly decreased as compared to previous years, when it was in the range of 801-839 $\mathrm{m}$.

Width of the river channel was found to change on the entire stretch of Vistula river in the analyzed period of 35 years. Taking into account the increase and decrease of the river channel width in subsequent years, it was found that it has been narrowed by an average of $24 \mathrm{~m}$ throughout the studied period.

Since the beginning of 1970 s, regulatory works have begun consisting in narrowing the river channel by means of constructing the groins and seawalls, both on the left and right banks. The most visible effect of these treatments can be seen in the area of Kępa Wyszogrodzka, Kępa Kamińskich, and Kępa Sempławska. These works resulted in, among others, deepening the main river channel near Kępa Wyszogrodzka and separating the river channel into two strands at km 590-594 (Kępa Sempławska); the left bank branch is the main one and is deeper. After completing the regulatory works, the embankment erosion process and the local increase in the river channel width was observed between groins. 
After some time, erosion between groins began to fade in favor of accumulation, which resulted in an accelerated process of the river channel width decrease and deepening the stream (Banach 1998). Accumulation of river material, resulting in narrowing the river channel, is also visible in the right bank of the river (km 603-605). Based on the analysis of the river channel width in this region, the disappearance of islands located above Kępa Stobieckiego, was observed. This is due to the decrease in the river channel width on this stretch by about $350 \mathrm{~m}$ during 40 years of observation.

Length of the riverbanks of the analyzed section of the Vistula river in the early 1970 s, averaged for the right bank of about $37 \mathrm{~km}$ and about $40 \mathrm{~km}$ for the left bank. In subsequent years, changes of this parameter were caused by both natural factors and those associated with human activity. During the analyzed period, a decrease in the left bank length and increase in the right bank length in relation to values at the beginning of 1970s, was recorded (Table 2).

In 1972-1974, the outline of the riverbanks of the test section was very varied, there were numerous bays and embankment fluvial deposits. This is reflected in the length of the riverbanks, which for the left bank was then the longest and amounted to about $40 \mathrm{~km}$, while at the same time, the right bank was shorter by almost $3 \mathrm{~km}$. In 1982, both banks of the river were shortened. Changing the length of the right bank (by approximately $1.3 \mathrm{~km}$ ) was caused by the disappearance of two river branches located near Zakrzewo Kościelne and above Kępa Polska at km 606 of the river course. Reduction of the left bank length from 40.0 to about $35.5 \mathrm{~km}$ was induced by backfilling of some river branches by debris as well as cutting off part of the point bars from the banks.

In the following period (1982-1992), there was a gradual increase in the length of both banks, that in 1992 had a length of: right bank - about $36.8 \mathrm{~km}$, left bank $-38.1 \mathrm{~km}$. In subsequent years, length of the right bank rose again to about $38.2 \mathrm{~km}$ in 2003, whereas length of the left riverbank decreased compared to the length in 1992 and finally amounted to about $37.4 \mathrm{~km}$. The reason for this was to disconnect the left riverbank point bar located between $\mathrm{km} 583$ and $\mathrm{km}$ 584 of the river course. In the period 2003-2009, reduction in the length of both banks by $0.8-0.9 \mathrm{~km}$, was recorded (Table 2, Fig. 2).

TABLE 2. Length of the riverbanks on the Vistula river reach Czerwińsk-Kępa Polska (km 576-609)

\begin{tabular}{|c|c|c|c|c|}
\hline \multirow{2}{*}{ Year } & \multicolumn{2}{|c|}{$\begin{array}{c}\text { Length of the riverbanks } \\
(\mathrm{km})\end{array}$} & \multicolumn{2}{c|}{$\begin{array}{c}\text { Changes of riverbanks length's in } \\
\text { the following period }(\mathrm{km})\end{array}$} \\
\cline { 2 - 5 } & left bank & right bank & left bank & right bank \\
\hline 1974 & 40.0 & 37.1 & - & - \\
\hline 1982 & 35.5 & 35.8 & -4.5 & -1.3 \\
\hline 1992 & 38.1 & 36.8 & 2.6 & 1.0 \\
\hline 2003 & 37.4 & 38.2 & -0.7 & 1.4 \\
\hline 2009 & 36.6 & 37.3 & -0.8 & -0.9 \\
\hline
\end{tabular}




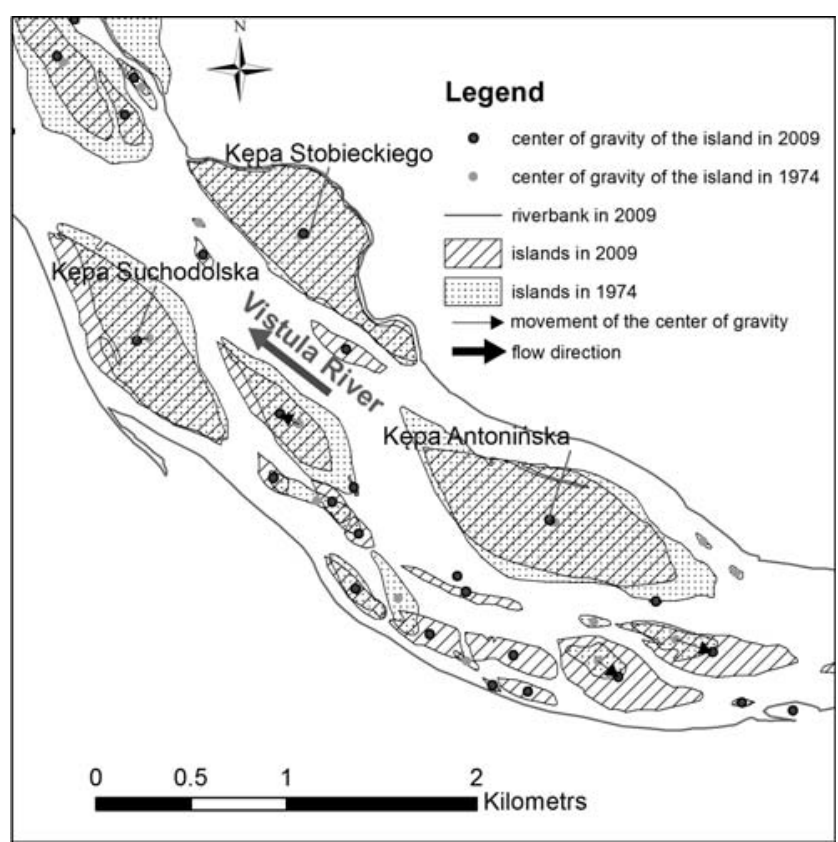

FIGURE 2. Changes of shape end gravity center of islands on the Vistula river reach km 596-602

No significant changes in the position of the main river channel, but only its banks alterations were found in analyzed section. Accumulated material buried narrow river branches causing the merging of numerous coastal islands with a bank. These phenomena usually occurred during the floods. It can be assumed that these changes resulted from extremely low water levels observed in 1982-1991. Later, there was an increase in flows (including flood in 1997), which resulted in greater erosion changes in analyzed section of Vistula river.

Interesting observations relate to changes in the position of islands within Vistula river channel. Two island types can be distinguished: so-called islands - permanent islands with high vegetation as well as sandy fluvial deposits. These structures differ significantly in their change of shapes and rate of movement in the river channel. Works carried out by other authors (Babinski 1992, Ashworth and Lewin 2012) indicate that sandy point bars move at a rate dependent on hydrological conditions. In the case of increasing flow by approximately $30 \%$ (about $1 \mathrm{~m}$ upstream from the mean water level), more than twofold increase in the movement rate of the point bars head from about $0.7-1.0 \mathrm{~m}$ per day to more than $2.0 \mathrm{~m}$ per day, occurs. Point bars are more stable structures. Majority of islands analyzed in details have been present at least for 200 years. This can be seen when comparing the old cartographic materials such as map from 1888 (Fig. 3).

In 1974, the analyzed section of Vistula river was characterized by the presence of a large number of islands and 


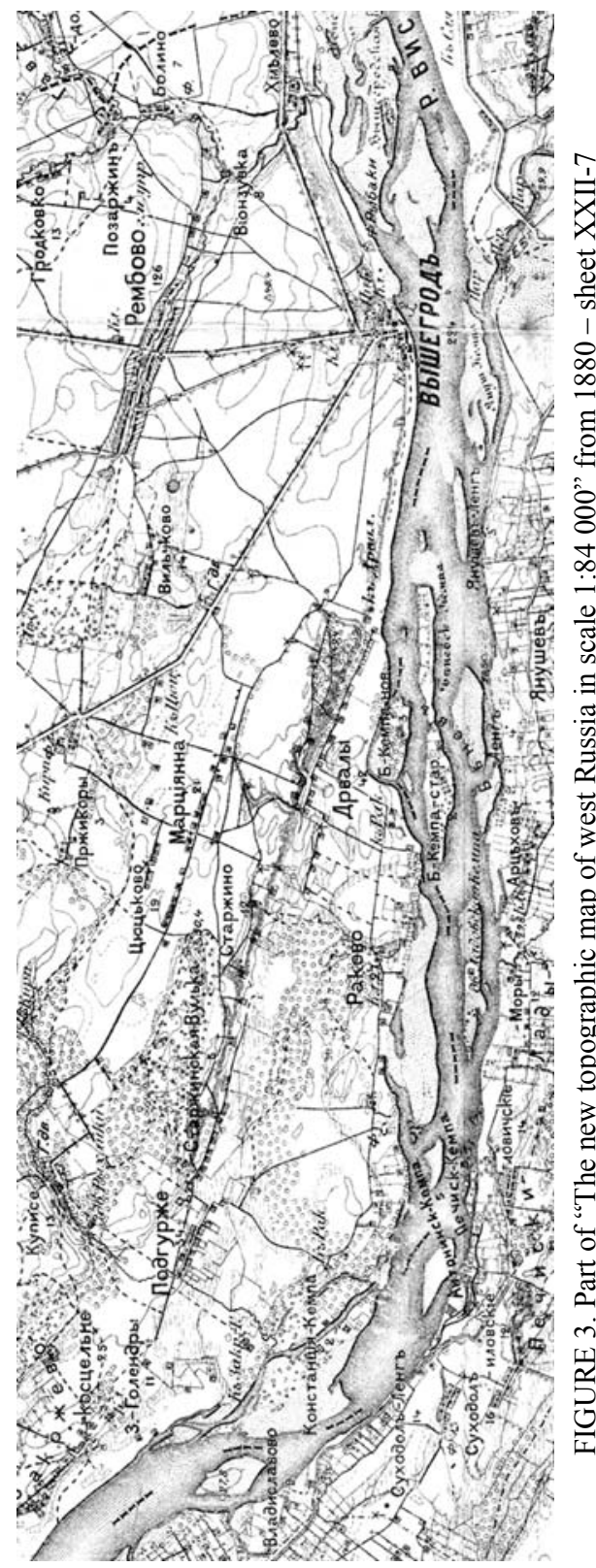

fixed fluvial deposits (106), the total area of which was $14 \mathrm{~km}^{2}$, which accounted for approximately $39.2 \%$ of the main river channel area. In 1982 and 1992, there was a smaller number of forms in Vistula river channel and their area, as compared to 1974, decreased to an average about $11.9 \mathrm{~km}^{2}$ in 1992 . Percentage of the point bars area in both these years was more or less similar and averaged about $35 \%$ of the total river channel area. In period 2003-2009, an increase in the number of islands (up to 147) and their area to $12.1 \mathrm{~km}^{2}$, was observed. The space occupied by persistent islands accounted for $36 \%$ of the Vistula river channel in 2009 (Table 3).

During the study period, considerable changes in the area were also observed in the case of the largest islands located in the analyzed section of Vistula river. Following islands were subject to analysis: Wyszogrodzka (km 583-587), Sempławska and Bieniaw Stary $(\mathrm{km}$ 590-593), as well as groups of islands: Rakowska, Grzegorków, Kamińskich, Ładowska (km 594-597), as well as Antonińska, Suchodolska, and Stobieckiego located at km 599-603 of the river course (Table 4).

On the map from 1974, Kępa Wyszogrodzka had an area of $2.09 \mathrm{~km}^{2}$. In 1982-2003, area of the island steadily declined up to $1.62 \mathrm{~km}^{2}$. The largest decrease in the area was observed in 1982 and 2003, which amounted to 11.4 and $9.8 \%$ in relation to the area occupied in previous years. Its front part and bank at the side of the mainstream between $\mathrm{km}$ 583-584, as well as fragment nearby the bridge pylons in Wyszogród, was subject 
TABLE 3. Number of islands, their area and percentage portion in total river channel area on the Vistula River reach Czerwińsk-Kępa Polska (km 576-609)

\begin{tabular}{|c|c|c|c|c|}
\hline Year & $\begin{array}{c}\text { Number of } \\
\text { islands }\end{array}$ & $\begin{array}{c}\text { Islands area } \\
\left(\mathrm{km}^{2}\right)\end{array}$ & $\begin{array}{c}\text { Total river channel } \\
\text { area } \\
\left(\mathrm{km}^{2}\right)\end{array}$ & $\begin{array}{c}\text { Portion of islands in } \\
\text { river channel area (\%) }\end{array}$ \\
\hline 1974 & 106 & 14.01 & 35.75 & 39.2 \\
\hline 1982 & 84 & 12.11 & 34.68 & 34.9 \\
\hline 1992 & 86 & 11.86 & 34.31 & 34.6 \\
\hline 2003 & 124 & 9.87 & 34.48 & 28.6 \\
\hline 2009 & 147 & 12.11 & 33.86 & 35.8 \\
\hline
\end{tabular}

to erosion. Cutting the narrow piece of islands located on the south-western tip was the greatest impact on reduction of the island area, which gave rise to separate island. In 2009, it was found an increase of Kępa Wyszogrodzka by more than $28 \%$ to $2.08 \mathrm{~km}^{2}$ (i.e. close to the area in 1974) due to the re-connection of previously cut island fragment on the south-western tip. Also geometric center of the island was shifted in this direction by about $150 \mathrm{~m}$ (Table 4).

The second largest island is Kępa Sempławska/Bieniaw Stary. In the past, these were two separate islands, that in the 1970 s were merged. In the period 1974-1992, the island area increased from $1.77 \mathrm{~km}^{2}$ in 1974 to $1.86 \mathrm{~km}^{2}$ in 1992. It was due to burying the bays located in the southern part of the island and accumulation of the river channel material in the western and eastern parts of the island. In 1992-2003, its area was reduced by $7.7 \%$, reaching the size of $1.73 \mathrm{~km}^{2}$. According to Banach (1998), the reason for these changes was the erosion from the left bank, as well as formation of the bay in the western part of island. In 2009, it was found the re-growth of the area to $1.83 \mathrm{~km}^{2}$ and disappearance of previously formed bays.
Geometrical center of the island during 35 years moved about $70 \mathrm{~m}$ to the south, i.e. the left bank of the Vistula river.

In the central fragment of the test river section, there are two island groups. The first contains the largest island Kępa Rakowska $\left(0.51 \mathrm{~km}^{2}\right)$, while the second - Kępa Antonińska $\left(0.74 \mathrm{~km}^{2}\right)$. The area of both islands were reduced in period from 1974 to 1992. The largest decrease in the island area was recorded in 1992 and amounted to 11.9 and $12.6 \%$, respectively as compared to the previous state. In 2003, there was a growth of Kepa Rakowska area by $7.7 \%$ (to $0.46 \mathrm{~km}^{2}$ ) due to merging with two smaller islands situated in the south-western end. In 2009, the island has an area of $0.44 \mathrm{~km}^{2}$. Its geometric center changed position by $92 \mathrm{~m}$ in the south-west direction, obliquely to the Vistula river stream flow and the left bank of the river.

In the case of Kępa Antonińska, a systematic reduction of its area in analyzed periods was observed, up to the value of $0.74 \mathrm{~km}^{2}$ in 1974 and to $0.56 \mathrm{~km}^{2}$ in 2009 (Table 4, Fig. 2). The center of the island was slightly shifted by $34 \mathrm{~m}$ in the direction of the main stream of the river. Two smaller islands located at the height of Kępa Antonińska head in the left part 


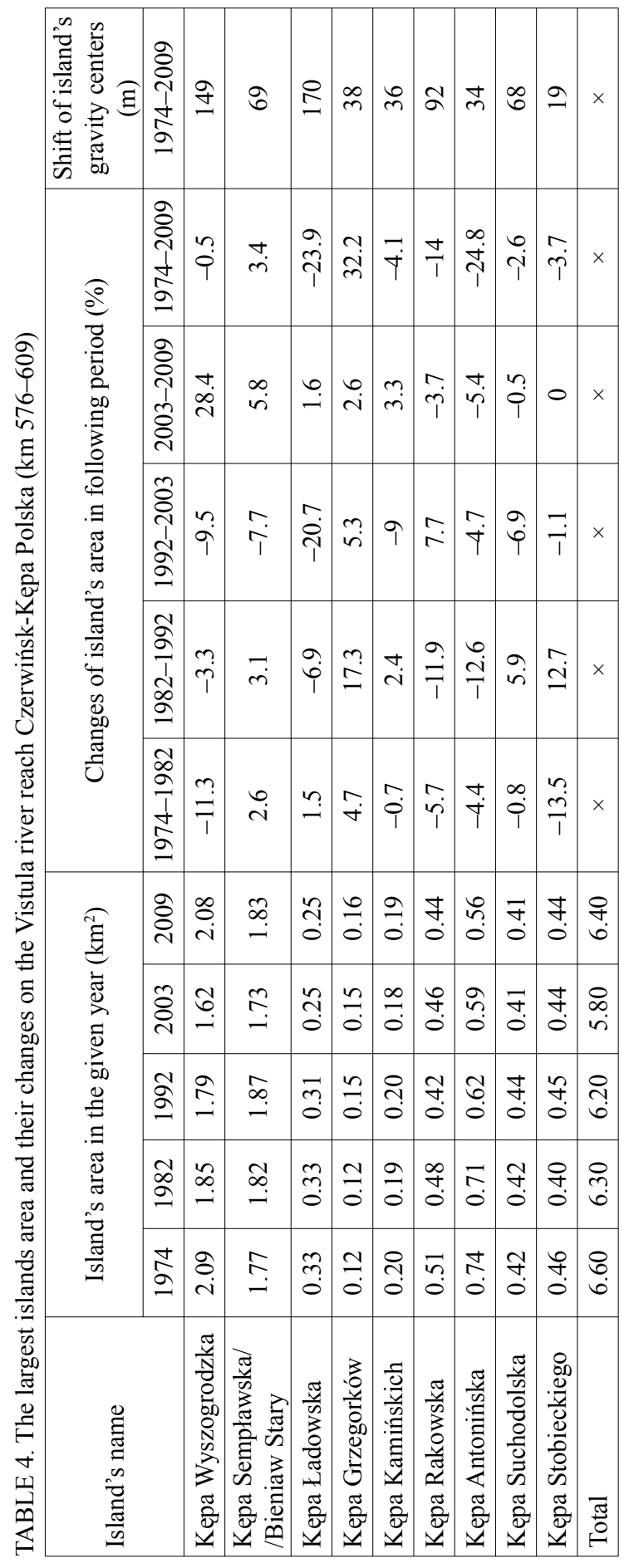


of Vistula river channel, significantly increased their surface in 1974-2009, and their geometric centers were shifted respectively by 135 and $200 \mathrm{~m}$ upstream (Fig. 2). The reason for these changes was the accumulation of debris on the left side of Vistula river channel due to destruction of groin constructed on the right riverbank in 1960s and two dams located between Kępa Antonińska and the right bank of the river. As a result of the destruction of the regulatory building, there was some shift of the Vistula river mainstream from the central part of the river channel to that located at the right bank.

Analysis of changes in the area of other islands showed an alternating tendency to their decrease and increase (Table 4). The largest decrease in area (by $20.7 \%$ ) was recorded in 1992-3003 for Kępa Ładowska. In contrast, the smallest loss of area concerned Kępa Kamińskich and Kępa Suchodolska in 1974-1982. Kępa Stobieckiego did not change its area during 2003-2009. The greatest stability characterized islands: Kamińskich, Suchodolska, and Stobieckiego - within 35 years, their area decreased only by about 3-4\% (Table 4).

Within studied area, a trend to a decrease in the number and area of sandy fluvial deposits, as well as percentage of occupied area in the river channel, was observed. Detailed information in this regard, however, relate to the morphological changes that occurred at a much shorter distance at km 596-602 of the Vistula river, i.e. near Kępa Rakowska and Kępa Antonińska (Popek and Wasilewicz 2013). Based on the analysis of the river channel in 2000 and 2009, it was found that the proportion of sandy fluvial deposits within this stretch decreased by $2 \%$, while the share of all permanent vegetated islands (i.e. including the above-mentioned islands) increased by $0.4 \%$. The reason for the increase in the area of islands is the intensive development of high vegetation (mainly willow), that stabilizes the fluvial deposits and accelerates the accumulation of bed load. High vegetation on the islands additionally makes greater resistance to flow, which increases the speed and concentration of flood water flow in streams of the river channel. This situation, in turn, is not conducive to the accumulation of river channel material in the form of sandy point bars. This should explain the decrease in area of fresh sandy fluvial deposits, which in 2000 occupied the area of 154 ha in Vistula river channel (17.7\%), while in 2009-134 ha (15.7\%). Similar processes in the Vistula river near Warsaw (km 495-498) was observed by Falkowski and Ostrowski (2012) but the main reason of sandy fluvial deposits decreasing was specific geological conditions and former river training works, which led to artificial narrowing of river channel.

\section{CONCLUSIONS}

Analysis of archival cartographic and remote sensing materials showed that average width of the Vistula river channel within tested section was reduced by $24 \mathrm{~m}$ in 1974-2009. Regulatory works carried out in the Vistula since early 1970 s, as well as low water levels observed especially in 1982-1992, can be 
indicated as the reason for these changes. The largest decrease in the river channel width, averaging to $200 \mathrm{~m}$, was observed in the initial and final parts of the test section, i.e. in the area of $\mathrm{km}$ 578-579, $\mathrm{km} \mathrm{603,} \mathrm{and} \mathrm{km} \mathrm{607.} \mathrm{On} \mathrm{the}$ other hand, the largest increase in river channel width of about $100 \mathrm{~m}$ occurred at km 608 in Kępa Polska.

Based on the study, it was found that during 35 years, the length of both riverbanks was changed. These changes were caused by both natural and anthropogenic factors. During analyzed period, a decrease in the length of left bank of about $3 \mathrm{~km}$ was observed, while the right edge length increased slightly by $0.2 \mathrm{~km}$. Analysis of the banks position showed that the primary factor of changes in main river channel was the accumulation of material at the edges, which is largely the result of regulatory buildings. Erosion of the Vistula riverbanks occurred to a clearly lesser extent.

In 1974, 106 islands were present within test section of the river, and they occupied a total of approximately $14.0 \mathrm{~km}^{2}(39 \%$ of the river channel area). In subsequent years, there has been both decline in their number and the space occupied in the river channel. In 2009, an increase to 147 islands was recorded, but they were mostly structures of a very small area, so that the total area decreased to $12.1 \mathrm{~km}^{2}$, and the percentage to $36 \%$ of the river channel area.

Analysis of changes in area of nine largest permanent islands showed that the predominant trend is the decrease of their area as a result of erosion processes - such changes referred to seven is- lands. Although the total area of islands decreased slightly from 6.6 to $6.4 \mathrm{~km}^{2}$, in the case of individual islands the area changes were much larger. During the 35-year period, the greatest area loss by 24-25\% occurred on Kępa Antonińska and Kępa Ładowska. In contrast, the largest increase was recorded in the case of Kępa Grzegorków - its area increased by about $32 \%$.

Based on the analysis of the gravity center of selected islands, it was found that their position in Vistula river channel changes. Shifting of the gravity center during 35 years ranged from 19 to $170 \mathrm{~m}$, and the direction was different - both in line with the flow and directed opposite (upstream), as well as directed towards the bank of the main Vistula river channel.

\section{REFERENCES}

ASHWORTH P.J., Lewin J. 2012: How do big rivers come to be different? Earth-Science Reviews 114, 84-107.

BANACH M. 1998: Dynamika brzegów dolnej Wisły [Riverbanks dynamics of the lower Vistula River]. Dokumentacja Geograficzna $n r$ 9, Instytut Geografii i Przestrzennego Zagospodarowania PAN, Kraków.

BABIŃSKI Z. 1992: Współczesne procesy korytowe dolnej Wisły [Present-day riverbed processes of the lower Vistula River]. Wydawnictwo PAN, Wrocław, Warszawa, Kraków.

BAJKIEWICZ-GRABOWSKA E., DANIELAK D. 1996: Dolina Wisły pod Płockiem - ogólna charakterystyka środowiska przyrodniczego [The Vistula River valley near Płock - general characteristics of nature environment]. In: Eds. M. Mikulski, E. Bajkiewicz-Grabowska. Ekologiczne podstawy zagospodarowania dolin rzecznych (na przykładzie Wisły pod Płockiem) [Principle of river valley spa- 
tial organization (on the example the Vistula River near Płock)]. Towarzystwo Naukowe Warszawskie, Warszawa, 27-38.

FALKOWSKI T., OSTROWSKI P. 2012: Wpływ budowy geologicznej na zróżnicowanie dynamiki procesów korytowych w warunkach silnej antropopresji na przykładzie Wisły warszawskiej [Geologic structure influence on channel processes of regulated river in example of the Vistula River reach in Warsaw]. Acta Geographica Lodziensa 100, 51-63.

KONDRACKI J. 1994: Geografia Polski. Mezoregiony fizyczno-geograficzne [Geography of Poland. Physical-geographic mesoregions]. Wydawnictwo Naukowe PWN, Warszawa.

POPEK Z., FALKOWSKI E., OSTROWSKI P., WASILEWICZ M. 2009: Charakterystyka morfologiczna koryta Wisły na odcinku od km 596 do km 602 oraz ocena czynników wpływających na jego stan w aspekcie utrzymania dobrego stanu przyrodniczego rzeki [Morphological characteristics of the Vistula riverbed on the reach km 596-602 and evaluation of factors affected on the state in aspect of maintain a good nature condition of river]. Ekspertyza dla RZWG w Warszawie, Katedra Inżynierii Wodnej SGGW, Warszawa.

POPEK Z., WASILEWICZ M. 2013: Obszar Natura 2000 „Dolina Środkowej Wisły” a zagrożenie powodziowe - analiza przypadku [, ,The Midlle Vistula River Valley" Nature 2000 area and flood threats - case study]. In: Ed. B. Pawluśkiewicz. Gospodarowanie w dolinach rzecznych na obszarach Natura 2000 [Management in river valleys on the Nature 2000 areas]. Wydawnictwo SGGW, Warszawa, 135-145.

RUSZCZYŃSKA-SZENAJCH H. 1970: Objaśnienia do Szczegółowej Mapy Geologicz- nej Polski, Arkusz Wyszogród (N34-125C) w skali 1:50 000 [Comments to the Detailed Geological Map of Poland, Wyszogród sheet (N34-125C) in scale 1:50 000]. Wydawnictwo Geologiczne, Warszawa.

Streszczenie: Zmienność warunków morfologicznych koryta Wisty na odcinku Czerwińsk-Kęa Polska. W pracy przedstawiono ocenę zmian morfologicznych, jakie wystapiły w korycie rzeki Wisły na wybranym odcinku o długości około $33 \mathrm{~km}$, położonym w środkowym biegu Wisły między Czerwińskiem a Kępą Polską (km 576-609). $\mathrm{Na}$ podstawie analizy materiałów archiwalnych z lat 1972-2009 uzyskano charakterystykę zmian koryta, biorąc pod uwage przede wszystkim układ poziomy (ukształtowanie w planie). Podjęto próbę oszacowania tendencji i prędkości przekształceń w korycie następujących parametrów: szerokość koryta, długość i położenie linii brzegowej, liczebność i powierzchnia kęp i odsypisk, a także ich procentowy udział w całkowitej powierzchni koryta głównego i obszaru międzywala.

Słowa kluczowe: morfologia koryta rzecznego, rzeka roztokowa, rzeka Wisła

\section{MS. received October 2014}

\section{Author's addresses:}

Zbigniew Popek, Michał Wasilewicz

Katedra Inżynierii Wodnej, Wydział Budownictwa i Inżynierii Środowiska SGGW ul. Nowoursynowska 166, 02-787, Warszawa

Poland

e-mail: zbigniew_popek@sggw.pl

michal_wasilewicz@sggw.pl 